\title{
Marketing Practices of Resorts in Cuyapo, Nueva Ecija: Implications to Business and Social Studies
}

\author{
Eileen Joy S. Domingo
}

\begin{abstract}
The study presented the marketing practices of selected resorts in Cuyapo, Nueva Ecija. The study aimed to assess different marketing practices with focus on product offering, pricing and promotion of the selected resorts along with getting the satisfaction of the customers with the practices. The results of the study also highlighted the implications to business and social studies. The descriptive method of research was utilized and the normative survey technique was used for gathering data. The questionnaire served as the instrument for collecting data. Owners/ managers of three selected resorts in Cuyapo, Nueva Ecija were taken as respondents. Only the customers who were in the resorts during the data gathering period comprised the customer respondents. Pearson correlation and descriptive statistics such as weighted mean and percentages were primary statistical tools used in analyzing and interpreting the research data.
\end{abstract}

Keywords - marketing, pricing, product, promotion, resorts.

\section{INTRODUCTION}

Resorts operate in a very competitive tourist accommodation market, with a variety of accommodation styles and quality available at a range of prices points to suit particular needs. Resort industry in the Philippines is booming and because it is a tropical country, resorts have a high demand especially during summer season. Because of its increasing demand, capitalists are now investing their money in putting up resorts.

In Municipality of Cuyapo in Nueva Ecija, more number of resorts are now operating with some of them making impact in the resort industry and becoming a must see destination by the tourists and sightseers. With the growing competition, resorts must pay attention on their marketing strategies since customers are influenced with the promotion, price and product of the resorts to Domingo (2018) marketing plays a very important role in the organization's success; it is a must to every organization to consider strategizing their different marketing practices.

The objective of this research is to explore marketing practices in the resort industry in terms of product offering, pricing, and promotion along with the relationship of customers' satisfaction with such practices.

Information on resort marketing practices is available through both industry and academic publications but these sources offer a limited depth of understanding. Numbers of studies about companies marketing practices have already been conducted. Despite of its growing importance, resort businesses' marketing practices remains an under researched area. A study that addresses this research gap is therefore necessary hence; the need for this study was realized.

Furthermore, the study could also impact business and social studies in through inspiring businessmen to be socially responsive and responsible.

\section{OBJECTIVES OF THE STUDY}

The study aimed at describing marketing practices of selected resorts in Cuyapo in Nueva Ecija. Specifically to:

1. Describe the profile of the resorts be described in terms of:
$1.1 \quad$ Type of ownership
1.2 Number of employees
1.3 Years of existence

2. Describe the marketing practices of selected resorts be described in terms of:
2.1 Product offering
2.2 Pricing
2.3 Promotion

3. Determine if there a significant relationship between the marketing practices of resorts and the business related factors

4. Describe the level customers' satisfactions be assessed in terms of:

4.1 Product offering

$4.2 \quad$ Pricing

4.3 Promotion

5. Describe the implications of the study to Business and Social Studies. 


\section{METHODOLOGY}

The study used descriptive method of research in an attempt to analyze and interpret the Marketing Practices of Selected Resorts in Cuyapo, Nueva Ecija. The respondents of the study were the owners of three resorts in Cuyapo Nueva Ecija. Customers were also considered and assessed their satisfaction level towards the resorts' marketing practices. Only the customers who were in the resorts during the data gathering period comprised the customer respondents. Questionnaire was the main instrument used by the researcher in conducting this study. Questionnaire was structured based on the study of Sangkaworn, C. and Mujtaba, B., (n.d.).

\section{RESULTS AND DISCUSSION}

\section{Profile of the resorts}

As to type of ownership, all resorts are under sole proprietorship type. As to number of employees the three resorts have more than 10 employees. In addition, one (1) resort is operating for 2-5 years, one (1) is in business for 6-8 years and one (1) is in resort industry for more than 15 years now.

\section{Marketing Practices of Resorts}

\section{Product Offering}

The level of implementation of marketing practices of selected resorts in Cuyapo, Nueva Ecija in terms of product offering is presented in Table 1.

Table.1: Marketing Practices of Resorts in terms of Product Offering

\begin{tabular}{|c|c|c|}
\hline PRODUCT OFFERING & $\begin{array}{l}\text { Weighted } \\
\text { Mean }\end{array}$ & Description \\
\hline $\begin{array}{l}\text { 1. Sanitation and } \\
\text { cleanliness of the } \\
\text { Resorts and their } \\
\text { surroundings }\end{array}$ & 5 & Always \\
\hline $\begin{array}{ll}\text { 2. Prompt courteous } \\
\text { service }\end{array}$ & 5 & Always \\
\hline $\begin{array}{l}\text { 3. Availability of } \\
\text { parking space }\end{array}$ & 4.33 & Always \\
\hline 4. Food and beverages & 5 & Always \\
\hline $\begin{array}{l}\text { 5. Good and proper } \\
\text { ventilation }\end{array}$ & 5 & Always \\
\hline $\begin{array}{l}\text { 6. } \begin{array}{l}\text { Completeness of } \\
\text { swimming facilities }\end{array}\end{array}$ & 4.67 & Always \\
\hline $\begin{array}{ll}\text { 7. } & \text { Recreational } \\
\text { Facilities }\end{array}$ & 4.67 & Always \\
\hline $\begin{array}{ll}\text { 8. } & \text { Customer } \\
& \text { information service }\end{array}$ & 4.33 & Always \\
\hline
\end{tabular}

\begin{tabular}{|c|c|c|}
\hline $\begin{array}{l}\text { 9. } \\
\begin{array}{l}\text { Attractiveness of } \\
\text { arrangement of } \\
\text { rooms/cottages }\end{array}\end{array}$ & 4.33 & Always \\
\hline $\begin{array}{l}\text { 10. Proper arrangement } \\
\text { Facilities }\end{array}$ & 5 & Always \\
\hline Total & $\mathbf{4 . 7 3}$ & Very High \\
\hline \multicolumn{2}{|c|}{ Items 1, 2, 4, 5, and 10 got a weighed mean of }
\end{tabular}

5.00 and rated "always". They consider the sanitation and cleanliness of the resorts and their surroundings, coupled with prompt and courteous service, food and beverages, good and proper ventilation and proper arrangement of facilities.

Meanwhile, considerations 6 and 7 both got weighted mean of 4.67 and rated "always". This denotes that they consider the completeness of swimming and recreational facilities.

On the other hand, items 3,8 and 9 got a weighted mean of 4.33 and rated "always". This implies that resorts consider the availability of parking space, customer information service, and attractiveness of arrangement of cottages.

The results show that the selected resorts in Cuyapo, Nueva Ecija have a "Very High" $(X=4.73)$ level of marketing practices in their product offerings.

These are the main factors they considered in the operation of the business in order to attract and retain loyal customers.

a. Pricing

Table 2 displays the level of implementation of marketing practices of resorts in terms of pricing.

Table 2. Marketing Practices of Resorts in terms of Pricing

\begin{tabular}{|c|c|c|}
\hline PRICING & $\begin{array}{c}\text { Weighted } \\
\text { Mean }\end{array}$ & Description \\
\hline \multicolumn{3}{|l|}{$\begin{array}{l}\text { The management uses the } \\
\text { following means of pricing }\end{array}$} \\
\hline $\begin{array}{l}\text { 1. } \text { Based on } \\
\text { cost/expense of } \\
\text { product }\end{array}$ & 3.67 & Very Often \\
\hline 2. $\quad$ Based on demand & 4 & Very Often \\
\hline $\begin{array}{ll}\text { 3. } & \text { Psychological (e.g. } \\
& \text { P 991.95,P399) }\end{array}$ & 4 & Very Often \\
\hline 4. Discount & 4.33 & Always \\
\hline $\begin{array}{l}\text { 5. Based on the price } \\
\text { of competitors }\end{array}$ & 3 & Often \\
\hline $\begin{array}{l}\text { Internal factors affecting } \\
\text { pricing decision }\end{array}$ & & \\
\hline
\end{tabular}




\begin{tabular}{|c|c|c|}
\hline 1. Profit & 4 & Very Often \\
\hline 2. $\quad$ Available offer & 4 & Very Often \\
\hline 3. $\quad$ Cost & 4 & Very Often \\
\hline $\begin{array}{ll}4 . & \text { Business structure }\end{array}$ & 3 & Often \\
\hline \multicolumn{3}{|l|}{$\begin{array}{l}\text { External factors affecting } \\
\text { pricing decision }\end{array}$} \\
\hline $\begin{array}{l}\text { 1. The market and } \\
\text { demand }\end{array}$ & 3.67 & Very Often \\
\hline $\begin{array}{l}\text { 2. Competitors price } \\
\text { and offer }\end{array}$ & 3.33 & Often \\
\hline $\begin{array}{l}\text { 3. Other factors such } \\
\text { as political, } \\
\text { environmental, } \\
\text { demography, } \\
\text { economic condition } \\
\text { etc. }\end{array}$ & 3.67 & Very Often \\
\hline Total & 3.72 & High \\
\hline
\end{tabular}

As to pricing, item 4 got a weighted mean of 4.33. This means that they always offer discounts to their clients. Considerations number 1 and both 2 and 3 got a weighted mean of 3.67 and 4.00, respectively and rated "Very Often". This implies that they use cost/ expense, demand and psychological factors as their basis in pricing their products very often. Meanwhile, item 5 got a weighted mean of 3.00 and rated "often". This denotes that they often use the price of the competitors as their basis. According to some owners/managers they oftentimes used cost and discount in pricing in order to cover all the necessary expenses needed in the operation of the business and to retain customer loyalty.

As to internal factors that affecting their pricing decision, items 1, 2 and 3 got a weighted mean of 4.00 and rated "very often". The results show that they consider available offers, profit and cost as internal factors in pricing. On the other hand, consideration number 4 got a weighted mean of 3.00 and rated "oftentimes". This denotes that oftentimes, they consider the business structure as internal factors in pricing decision.

As to external factors affecting their pricing decisions, items 1 and 3 got a weighted mean of 3.67 and rated "Very often". This implies that they very often consider market and demand and other factors such as political, environmental, demography, economic condition, etc. as external factors in price considerations. On the other hand item 2 got a weighted mean of 3.33 and rated "often". This denotes that they often consider also the price of their competitors as external factors in pricing decision.
It can be gleaned from the results that there is a "High" (X=3.72) level of marketing practices of the resorts in terms of pricing.

Since price is the only element among the P's of marketing mix that generates income, owner/managers of resorts always see to it that prices are fair and affordable in order to retain customers.

\section{b. Promotion}

Level of implementation of marketing practices of the resorts in terms of promotion is shown in Table 3.

As to factors observed to capture and maintain customers' loyalty, considerations 2 and 4 and got a weighted mean of 4.00 and 3.67, respectively and rated "very often. This denotes that they provide additional amenities such WiFi, radio and television plus cable TV, Telephone/intercom, greeting customers and being friendly and they also provide customers with clean and ventilated rooms/cottages. On the other hand, item 6 got a weighted mean of 1.00 and rated never. This implies that they never consider giving gifts and souvenirs.

Table.3: Marketing Practices of Resorts in terms of Promotion

\begin{tabular}{|c|c|c|}
\hline Promotion & $\begin{array}{l}\text { Weighted } \\
\text { Mean }\end{array}$ & Description \\
\hline \multicolumn{3}{|l|}{$\begin{array}{l}\text { Factors observed to capture } \\
\text { and maintain Customers' } \\
\text { loyalty }\end{array}$} \\
\hline $\begin{array}{l}\text { 1. Giving customers' } \\
\text { discount }\end{array}$ & 3 & Often \\
\hline $\begin{array}{l}\text { 2. Providing additional } \\
\text { amenities such WiFi, } \\
\text { radio and television } \\
\text { plus cable TV, } \\
\text { Telephone/intercom }\end{array}$ & 4 & Very Often \\
\hline $\begin{array}{l}\text { 3. Providing additional } \\
\text { assistance }\end{array}$ & 3 & Often \\
\hline $\begin{array}{l}\text { 4. Greeting customers } \\
\text { and being friendly }\end{array}$ & 3.67 & Very Often \\
\hline $\begin{array}{llr}\text { 5. } & \text { Providing customers } \\
\text { with clean and } \\
\text { ventilated } \\
\text { rooms/cottages } & \\
\end{array}$ & 3.67 & Very Often \\
\hline $\begin{array}{ll}\text { 6. } & \text { Giving souvenirs and } \\
\text { gifts }\end{array}$ & 1 & Never \\
\hline \multicolumn{3}{|l|}{$\begin{array}{l}\text { The management uses the } \\
\text { following promotion practice }\end{array}$} \\
\hline 1. $\quad$ Personal selling & 3.33 & Often \\
\hline 2. Print media & 3 & Often \\
\hline
\end{tabular}




\begin{tabular}{|c|c|c|}
\hline 3. Sales promotion & 4.33 & Always \\
\hline \multicolumn{3}{|l|}{ Ways of advertising resorts } \\
\hline 1. Local radio & 2 & Sometimes \\
\hline 2. Local newspaper & 3.33 & Often \\
\hline 3. Brochures distributed & 3 & Often \\
\hline 4. Billboard nearby & 3.67 & Very Often \\
\hline \multicolumn{3}{|l|}{$\begin{array}{l}\text { The resorts observed the } \\
\text { importance of promotion }\end{array}$} \\
\hline $\begin{array}{l}\text { 1. The resorts have } \\
\text { sufficient budget for } \\
\text { advertising }\end{array}$ & 2.67 & Often \\
\hline 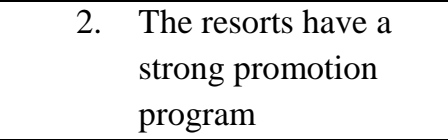 & 2 & Seldom \\
\hline $\begin{array}{l}\text { 3. Promotion affects the } \\
\text { volume of sales }\end{array}$ & 3.33 & Often \\
\hline $\begin{array}{l}\text { 4. The advertising } \\
\text { activities could reach } \\
\text { target clientele }\end{array}$ & 3.33 & Often \\
\hline Total & 3.08 & Fair \\
\hline
\end{tabular}

These are the most common factors to be considered in order to capture and maintain customers' loyalty, considering that customers are the ones who give income to the business in return for services.

As to their promotional practice, they always use sales promotion as promotion practice. Sales promotion got a weighted mean of 4.33. Meanwhile, oftentimes the management of the resorts consider print media and personal selling as a promotion practice. Print media and personal selling got a weighted mean of 3.33 and 3.00, respectively.

Billboards are very often used by the resorts. Billboards got a weighted mean of 3.67. Sometimes they consider local radio with a weighted mean of 2.00 . Oftentimes brochures are distributed through customers and used of local newspaper as a way to advertise their business. Brochures and news papers got a weighted mean of 3.00 and 3.33 , respectively.

It can be seen from the results that there is a "Fair" (X=3.08) level of implementation of marketing practices in terms of promotion.

Owners/managers expressed that they give much thought and time to promotions since they are very important for their organization's success. The reason why they spend time to craft an innovative promotion strategy is to capture the attention of existing and prospective customer.
Relationship between the marketing practices of resorts and the business related factors

Correlation between the business related factors and the marketing practices of resorts were also examined in this study. Pearson correlation was used to determine the relationship between the two variables.

As to product offerings. Based on the results shown in table 4, the obtained Person $r$ value for types of ownership and number of employees was -0.7559 which denotes strong negative correlation while years of service got a Person $r$ value of -0.4193 which denotes moderate negative correlation.

Table.4: Correlation between the Businesses Related Factors to Product Offering of Selected Resorts in Cuyapo, Nueva Ecija

\begin{tabular}{|l|c|c|c|}
\hline \multicolumn{1}{|c|}{$\begin{array}{c}\text { Business } \\
\text { Related } \\
\text { Factors }\end{array}$} & \multicolumn{3}{|c|}{ Product Offering } \\
\cline { 2 - 4 } $\begin{array}{l}\text { Types of } \\
\text { Ownership }\end{array}$ & $\begin{array}{c}\text { Interpretation } \\
0.7559\end{array}$ & $\begin{array}{c}\text { Degree of } \\
\text { correlation }\end{array}$ \\
\hline $\begin{array}{l}\text { Number of } \\
\text { Employees }\end{array}$ & - & $\begin{array}{c}\text { Not } \\
\text { Significant }\end{array}$ & $\begin{array}{c}\text { Strong } \\
\text { Negative } \\
\text { Correlation }\end{array}$ \\
\hline $\begin{array}{l}\text { Years of } \\
\text { Existence }\end{array}$ & -7559 & $\begin{array}{c}\text { Strong } \\
\text { Segative } \\
\text { Correlation }\end{array}$ \\
\hline $\begin{array}{l}\text { Average } \\
\text { Correlation }\end{array}$ & 0.4193 & Significant & $\begin{array}{c}\text { Moderate } \\
\text { Negative } \\
\text { Correlation }\end{array}$ \\
\hline
\end{tabular}

The results indicate that the marketing practices of the resorts have nothing to do with the present set up of the business. The product offering of the resorts are not influenced by the business related factors such as types of ownership, number of employees and years of existence.

The obtained average Person $r$ value of business related factors was -0.6437 which denotes strong negative correlation. The data reveals that all of the three businessrelated factors failed to surpass the $\mathrm{r}$ required at .05 probability level which is 0.997. Therefore, the null hypothesis which states that there is no significant correlation between the level of marketing practices of selected resorts in Cuyapo, Nueva Ecija and the aforementioned business-related factors cannot be rejected. This means that the level of marketing practices in terms of product offering is not significantly related to the type of ownership, capital, number of employees, and the years of existence. The level of marketing practices of resorts in 
terms of product offerings are not influenced by the type of ownership, number of employees and the years of existence.

As to pricing. Based on the results shown in table 5 , the obtained Person $r$ value for types of ownership was 0.6934 which denotes strong negative correlation while number of employees got a Person $r$ value of 0 which means no correlation. On the other hand, years of service got a Person $r$ value of 0.8846 which denotes very strong positive correlation.

Table.5: Correlation between the Business Related Factors to Pricing of Selected Resorts in Cuyapo, Nueva Ecija

\begin{tabular}{|c|c|c|c|}
\hline \multirow{2}{*}{$\begin{array}{c}\text { Business } \\
\text { Related } \\
\text { Factors }\end{array}$} & \multicolumn{3}{|c|}{ Pricing } \\
\hline & $\overline{\mathbf{r}}$ & Interpretation & $\begin{array}{c}\text { Degree of } \\
\text { correlation }\end{array}$ \\
\hline $\begin{array}{l}\text { Types of } \\
\text { Ownership }\end{array}$ & -0.6934 & $\begin{array}{c}\text { Not } \\
\text { Significant }\end{array}$ & $\begin{array}{c}\text { Strong } \\
\text { Negative } \\
\text { Correlation }\end{array}$ \\
\hline $\begin{array}{l}\text { Number of } \\
\text { Employees }\end{array}$ & 0 & $\begin{array}{c}\text { Not } \\
\text { Significant }\end{array}$ & $\begin{array}{c}\text { No } \\
\text { Correlation }\end{array}$ \\
\hline $\begin{array}{l}\text { Years of } \\
\text { Existence }\end{array}$ & 0.8846 & $\begin{array}{c}\text { Not } \\
\text { Significant }\end{array}$ & $\begin{array}{c}\text { Very Strong } \\
\text { Positive } \\
\text { Correlation }\end{array}$ \\
\hline $\begin{array}{l}\text { Average } \\
\text { Correlation }\end{array}$ & 0.06375 & $\begin{array}{c}\text { Not } \\
\text { Significant }\end{array}$ & $\begin{array}{c}\text { Slight } \\
\text { Correlation }\end{array}$ \\
\hline
\end{tabular}

The results indicate that the marketing practices of the resorts in terms of pricing have nothing to do with the present set up of the business. The business related factors are not necessary consideration on their pricing decision and practices.

The obtained average Person $r$ value of business related factors was -0.06375 which denotes slight correlation. The data reveals that all of the three businessrelated factors failed to surpass the $\mathrm{r}$ required at .05 probability level which is 0.997. Therefore, the null hypothesis which states that there is no significant correlation between the level of marketing practices of selected resorts in Cuyapo, Nueva Ecija and the aforementioned business-related factors cannot be rejected. This means that the level of marketing practices in terms of pricing is not significantly related to the type of ownership, capital, number of employees, and the years of existence. The level of marketing practices of resorts in terms of pricing are not influenced by the type of ownership, number of employees and the years of existence.
As to promotion. Based on the results shown in table 6, the obtained Person $r$ value for types of ownership and years of service was -0.2044 which denotes little negative correlation while number of employees got a Person $r$ value of 0 which denotes no correlation.

The results indicate that the marketing practices of the resorts in terms of promotion have nothing to do with the present set up of the business such as types of ownership, number of employees and years of existence. The business related factors are not considered by the selected resorts in their promotion practices.

Table.6: Correlation between the Business Related Factors to Promotion of Selected Resorts in Cuyapo, Nueva Ecija

\begin{tabular}{|l|c|c|c|}
\hline \multicolumn{1}{|c|}{$\begin{array}{c}\text { Business } \\
\text { Related } \\
\text { Factors }\end{array}$} & $\mathbf{3}$ & Interpretation & $\begin{array}{c}\text { Pegree of } \\
\text { correlation }\end{array}$ \\
\cline { 2 - 4 } $\begin{array}{l}\text { Types of } \\
\text { Ownership }\end{array}$ & -0.2044 & $\begin{array}{c}\text { Not } \\
\text { Significant }\end{array}$ & $\begin{array}{c}\text { Little } \\
\text { Negative } \\
\text { Correlation }\end{array}$ \\
\hline $\begin{array}{l}\text { Number of } \\
\text { Employees }\end{array}$ & 0 & $\begin{array}{c}\text { Not } \\
\text { Significant }\end{array}$ & $\begin{array}{c}\text { No } \\
\text { Correlation }\end{array}$ \\
\hline $\begin{array}{l}\text { Years of } \\
\text { Existence }\end{array}$ & -0.2044 & $\begin{array}{c}\text { Not } \\
\text { Significant }\end{array}$ & $\begin{array}{c}\text { Little } \\
\text { Negative } \\
\text { Correlation } \\
\text { Slight }\end{array}$ \\
\hline $\begin{array}{l}\text { Average } \\
\text { Correlation }\end{array}$ & -0.1363 & $\begin{array}{c}\text { Not } \\
\text { Significant }\end{array}$ & $\begin{array}{c}\text { Slion } \\
\text { Correlation }\end{array}$ \\
\hline
\end{tabular}

The obtained average Person $r$ value of business related factors was -0.1363 which denotes slight correlation. The data reveals that all of the three businessrelated factors failed to surpass the $\mathrm{r}$ required at .05 probability level which is 0.997. Therefore, the null hypothesis which states that there is no significant correlation between the level of marketing practices of selected resorts in Cuyapo, Nueva Ecija and the aforementioned business-related factors cannot be rejected. This means that the level of marketing practices in terms of promotion is not significantly related to the type of ownership, capital, number of employees, and the years of existence. The level of marketing practices of resorts in terms of promotion are not influenced by the type of ownership, number of employees and the years of existence.

\section{Customers' Satisfaction}

Table 7 presented the customers' satisfaction to measure the effectiveness of the different marketing practices of selected resorts in Cuyapo, Nueva Ecija. 
In terms of product offering, consideration number 5 and 6 got a weighted mean of 3.64 and 4.04, respectively. This implies that resorts' customers are much satisfied with the cleanliness and accommodation of the resorts. Items 1 and 4 got a weighted mean of 2.84 and 2.64 , respectively. This means that customers are satisfied with the service and ambiance of the resorts. On the other hand, considerations 2 and 3 got a weighted mean of 2.22 and 2.14, respectively. This implies that customers are moderately satisfied with the recreational facilities and the arrangement of facilities.

The results show that customers are satisfied with the different product offerings of the resorts.

Table.7: Customers' Satisfaction

\begin{tabular}{|c|c|c|}
\hline Customer Satisfaction & $\begin{array}{l}\text { Weighted } \\
\text { Mean }\end{array}$ & Description \\
\hline \multicolumn{3}{|l|}{ On Product Offering } \\
\hline 1. Quality of Service & 2.84 & Satisfied \\
\hline $\begin{array}{ll}\text { 2. } & \text { Quality of } \\
& \text { recreational facilities }\end{array}$ & 2.22 & $\begin{array}{c}\text { Moderately } \\
\text { Satisfied }\end{array}$ \\
\hline $\begin{array}{l}\text { 3. Arrangement and } \\
\text { presentation of } \\
\text { cottages }\end{array}$ & 2.14 & $\begin{array}{l}\text { Moderately } \\
\text { Satisfied }\end{array}$ \\
\hline 4. Ambiance & 2.64 & Satisfied \\
\hline 5. Cleanliness & 3.64 & $\begin{array}{c}\text { Much } \\
\text { Satisfied }\end{array}$ \\
\hline 6. Accommodation & 4.04 & $\begin{array}{c}\text { Much } \\
\text { Satisfied }\end{array}$ \\
\hline Total & 2.92 & Satisfied \\
\hline \multicolumn{3}{|l|}{ Pricing } \\
\hline $\begin{array}{l}\text { 1. Acceptance to the } \\
\text { price }\end{array}$ & 3.32 & Satisfied \\
\hline $\begin{array}{l}\text { 2. The prices vary } \\
\text { according to quality } \\
\text { of the services }\end{array}$ & 3.9 & $\begin{array}{c}\text { Much } \\
\text { Satisfied }\end{array}$ \\
\hline Total & 3.61 & $\begin{array}{c}\text { Much } \\
\text { Satisfied }\end{array}$ \\
\hline \multicolumn{3}{|l|}{ Promotion } \\
\hline $\begin{array}{l}\text { 1. The use of radio } \\
\text { advertising }\end{array}$ & 1 & Not Satisfied \\
\hline $\begin{array}{l}\text { 2. The use of discounts } \\
\text { as a promotion } \\
\text { strategy }\end{array}$ & 3.68 & $\begin{array}{c}\text { Much } \\
\text { Satisfied }\end{array}$ \\
\hline $\begin{array}{l}\text { 3. The use of local } \\
\text { newspaper }\end{array}$ & 1 & Not Satisfied \\
\hline $\begin{array}{l}\text { 4. The use of } \\
\text { billboard(s) }\end{array}$ & 2 & $\begin{array}{l}\text { Moderately } \\
\text { Satisfied }\end{array}$ \\
\hline $\begin{array}{l}\text { 5. The use of brochures } \\
\text { given to customers }\end{array}$ & 3.68 & $\begin{array}{c}\text { Much } \\
\text { Satisfied }\end{array}$ \\
\hline
\end{tabular}

\begin{tabular}{|l|c|c|}
\hline Total & 2.25 & $\begin{array}{c}\text { Moderately } \\
\text { Satisfied }\end{array}$ \\
\hline Overall & 2.92 & Satisfied \\
\hline
\end{tabular}

In terms of pricing, item 1 got a weighted mean of 3.332. This denotes that customers are satisfied with the price. On the other hand, consideration number 2 got a weighted mean of 3.90. This implies that the customers are much satisfied with the price variation.

In terms of promotion, items 2 and 6 both got a weighted mean of 3.68. This denotes that customers are much satisfied with the discounts and brochures given by the resorts. Consideration number 2 got a weighted mean of 2.00 which implies that customers are much satisfied with the billboards of the resorts. On the other hand, items 1 and 3 got a weighted mean of 1.00 which denotes that customers are not satisfied with the radio and news paper advertising of the resorts as their way of promotion.

Overall, the above results show that customers are satisfied with the product offering, pricing and promotional activities of the resorts with an overall weighted mean of 2.92 .

\section{Implications to Business and Social Studies}

This study was conducted to find out the marketing practices of selected resorts in Cuyapo, Nueva Ecija in terms of business-related factors which covered the type of ownership, number of employees, years of existence, the level of implementation of marketing practices along with product offering, pricing and promotion and their customers' satisfaction.

Since marketing now plays a very important role in the organization's success, it is a must to every organization to consider strategizing their different marketing practices. Presented herewith are the different considerations to which, if taken much attention would contribute to the success of company's marketing programs.

Attention on 3Ps would lead you to having a higher impact on the industry you are into. In addition, since business is about earning money, giving special attention on marketing could give an organization a favourable profit.

As for social studies, businessmen are not always profit-driven individuals. Resort owners continuously provide quality service to their customers because it is their social obligation to provide them satisfaction through their service offerings. Having a good corporate social responsibility can also be used as marketing strategy for a business as people patronized businesses which have a good reputation and provide customer-friendly, and safe 
place to be in. Most importantly, the customers value business that continuously maintains good relationship with them and doing something great to the society in general.

\section{CONCLUSION}

Based on the results of the study, the researcher arrived at the following conclusions:

a) All resorts are under sole proprietorship type and have more than 10 employees. In addition, one (1) resort is operating for $2-5$ years, one (1) is in business for 6-8 years and one (1) is in resort industry for more than 15 years now.

b) The level of implementation of marketing practices of selected resorts in Cuyapo, Nueva Ecija in terms of product offering is very high, as to pricing, the level of implementation is high, while as to promotion the level of implementation is fair.

c) There is no relationship between the business related factors and the marketing practices of the resorts in terms of product, pricing and promotion.

d) Customers are satisfied with the product offering, pricing and promotional activities of the resorts.

\section{REFERENCES}

[1] Domingo, A.V. (2018).Product, pricing and promotional strategies of Restaurants in Nueva Ecija: An Assessment. International Journal of Advanced Engineering, Management and Science(ISSN: 2454-1311),4(11), 753756. http://dx.doi.org/10.22161/ijaems.4.11.2

[2] Sangkaworn, C., Mujtaba, B., (n.d.). Marketing practices of hotels and resorts in ChiangMai: a study of products, pricing, and promotional practices. Retrieved from http://www.aabri.com/manuscripts/09383.pdf 